\title{
RESEARCH PAPER \\ Wind-induced leaning (toppling) in young Pinus radiata plantations in Chile
}

\author{
Manuel Toral ${ }^{1}$, Horacio E. Bown ${ }^{1}$, Alejandro Mañon ${ }^{2}$, José Alvarez ${ }^{3}$, and \\ Rafael Navarro-Cerrillo ${ }^{4}$ \\ 'Departamento de Gestión Forestal y su Medio Ambiente, Facultad de Ciencias Forestales y Conservación \\ de la Naturaleza, Universidad de Chile, Santa Rosa 11315, Santiago, Chile. \\ ${ }^{2}$ Programa de Naciones Unidas para el Desarrollo (PNUD), Dag Hammarskjold 3241, Vitacura, Chile. \\ ${ }^{3}$ Forestal Mininco S.A., Casilla 43-C, Concepción, Chile. \\ ${ }^{4}$ Departamento de Ingeniería Forestal Grupo PAI RNM 360 ETS Ingenieros Agrónomos y de Montes. Edf. \\ Leonardo da Vinci s/n. Campus de Rabanales. Apartado 3048. 14080 Córdoba, España.
}

\begin{abstract}
M. Toral, H.E. Bown, A. Mañon, J. Álvarez, and R. Navarro-Cerrillo. 2011. Wind-induced leaning (toppling) in young Pinus radiata plantations in Chile. Cien. Inv. Agr. 38(3): 405-414. The toppling of young trees considerably reduces the value of the first log in Pinus radiata plantations. Although wind is the main cause of toppling, the quality and type of plants, planting techniques, soil fertility and soil preparation may play an important role in the susceptibility of the species to toppling. This article analyzes the influence of ripping and soil type on the probability of $P$. radiata toppling after severe windstorms in central south Chile. To this aim, pairs of similar trees with and without toppling were selected in 2001 in six soil types with and without soil ripping. Root system differences in toppled versus straight trees were compared to gain better insight into the causes of the phenomenon. Among all root measurements, the quality of the tap root measured through the Menzies scale was significantly correlated with the probability of toppling. Trees with a strong, dominant and well-developed tap root (Menzies value equal to zero) showed a toppling probability of 0.34 ( 1 of each 3 trees being damaged). At the other extreme, trees with a horizontal tap root or with no tap root (Menzies value equal to 10) showed a toppling probability of 0.72 (i.e., three of each four trees were damaged). A toppling probability of 0.50 (or damage observed in one of each two trees) was found for trees with a tap root distinctly hooked but functional (Menzies value equal to 4). Ripping reduced the toppling probability from 0.56 to 0.44 by improving the quality of the tap root consistently across all soil types from Menzies 5.7 to Menzies 2.5. The worst tap root qualities were found for sandy soils (Menzies equal to 7.0 , toppling probability of 0.62 ), followed by metamorphic soils (Menzies equal to 4.5 , toppling probability of 0.52 ). Alluvial, granitic, red clay and volcanic ash soils did not differ in tap root quality (Menzies equal to 3.3, toppling probability of 0.47 ). In conclusion, the study suggests that all measures favoring a strong, dominant and well-developed tap root, in the nursery and in the field, are likely to considerably reduce toppling damage in young $P$. radiata plantations in Chile.
\end{abstract}

Key words: Ripping, soil fertility, tap root, toppling.

\section{Introduction}

Trees inclined by periodic wind stress (toppling) have been observed in Pinus radiata $\mathrm{D}$. Don plantations younger than three years old in New Zealand, Australia and Chile (Moore et al., 2008).

Received March 22, 2010. Accepted August 1, 2011.

Corresponding author: mtoral@uchile.cl
Sometimes toppling occurs after the formation of a small basin around the stem base as a result of wind-induced tree swaying, particularly in humid soils (Mason, 1985; Coxe et al., 2004).

Initial toppling recedes in most cases because the tree recovers straight growth; but during the recovery process, it develops sinuosity and com- 
pression wood that reduces the value of the first $\log$ (Coxe et al., 2004). Cown et al. (1984) found that the conversion yields from logs to sawn wood were $58 \%$ for straight logs, $52 \%$ for moderately curved logs and $46 \%$ for severely curved logs. The economic losses may reach up to $36 \%$ of the value of the first logs (Mason, 1985).

The risk of toppling damage in young $P$. radiata plantations depends on a combination of factors. According to Chavasse (1969) and Trewin (2003), greater damage in plantations is associated with strong rain, saturated soils and strong and turbulent winds. However, the susceptibility to wind damage also depends on a series of factors that may be controllable, such as the quality of nursery plants, plantation techniques, soil fertility, weed control and preventive treatments, such as crown trimming (Burdett et al., 1986; Moore et al., 2008). Except for trimming, all of the factors seem to be mediated by the extent and quality of the root system (Mason, 1985; Mason and Trewin, 1987).

Mason and Trewin (1987) weighted the quality of the root system as the most determinant factor for tree stability against strong winds. They observed that straight trees had a greater frequency of stronger and better quality tap and vertical roots compared with toppled trees. The authors concluded that the stability of young trees is associated with the development of a good system of secondary roots and an undeformed tap root.

It has been frequently stated that trees growing in fertile soils covered previously by pastures might be more susceptible to toppling damage (Aimers-Halliday et al., 1999; Davis-Colley and Turner, 2001). However, this perceived phenomenon is generally based on specific anecdotal, rather than formal, evidence (Coxe et al., 2004). In an inventory of 17 sites, Mason (1992) found higher toppling damage in low-productivity sites and at higher altitude, than in more fertile soils. This somewhat contradictory evidence raises reasonable doubts regarding how toppling is affected by soil fertility and what can be done to reduce it. Similar contradictions occur with the ripping effect prior to plantation (Mason, 1985). A growing number of researchers have shown a reduction in the carbon proportion assigned to roots in soils with high nitrogen (e.g., Santantonio and Santantonio, 1987; Beets and Whitehead, 1996; Bown et al., 2011). Therefore, trees growing in more fertile soils would have a lower root proportion and poorer anchoring than in less fertile soils; increasing their likelihood to suffer from toppling damage.

The aim of this study was to compare the root systems of straight versus toppled trees of twoyear-old Pinus radiata plantations with and without soil ripping across six soil types in central south Chile. The damage observed was caused by storms in July 2000, when gust speeds of up to $80 \mathrm{~km} \mathrm{~h}^{-1}$ were recorded. During that month, approximately 40,000 ha of plantations up to three years old were damaged in central south Chile (Cendoya and Muñoz, 2002). The hypotheses for the study are as follows: (i) straight trees would have a better quality and distribution of the root system compared with toppled trees; (ii) ripping would improve the development of the root system, diminishing the probability of toppling; and (iii) toppling would occur more frequently in fertile soils.

\section{Material and methods}

\section{Localization of the areas under study}

The plantations under study underwent toppling caused by wind in July 2000 (Cendoya and Muñoz, 2002). Trees were destructively sampled at twoyear-old plantations in the spring-summer 2001. Sampling was carried out in six locations, which corresponded to different soil types: MontoneraPencahue-Talca, with an alluvial soil $\left(35^{\circ} 18^{\prime} \mathrm{S}\right.$, $\left.71^{\circ} 49^{\prime} \mathrm{W}\right)$; Escuadrón-Coronel-Concepción, with a metamorphic soil $\left(37^{\circ} 03^{\prime} \mathrm{S}, 73^{\circ} 06^{\prime} \mathrm{W}\right)$; MisqueYumbel-Bío-Bío, with a sandy soil $\left(37^{\circ} 05^{` S}\right.$, $\left.72^{\circ} 33^{\top} \mathrm{W}\right)$; Huinanco-Yumbel-Bio-Bío, with a 
granitic soil $\left(37^{\circ} 08^{`} \mathrm{~S}, 72^{\circ} 49^{\prime} \mathrm{W}\right)$; Hijuela Los Chilcos-Galvarino-Cautín, with a red clay soil (38 $26^{`}$ S, $72^{\circ} 47^{`} \mathrm{~W}$ ); and LicancullinV-TolténCautín, with a soil derived from volcanic ashes that are called "trumaos" $\left(38^{\circ} 52^{\prime} \mathrm{S}, 73^{\circ} 06^{\prime} \mathrm{W}\right)$ (Figure 1). All of the plantations are from bare root seed plants grown for one year in the nursery.

According to the climatic information and agroclimatic districts from Santibáñez and Uribe (1993), the minimum mean for the coldest month varies in a relatively narrow range for the six studied sites between 4.1 to $5.9^{\circ} \mathrm{C}$. Likewise, the mean temperature varied between 11.5 and 13.6 ${ }^{\circ} \mathrm{C}$. The maximum means for the warmest month are higher for Montonera-Pencahue-Talca (28.9 ${ }^{\circ} \mathrm{C}$ ) and Yumbel-Bío-Bío $\left(28.6{ }^{\circ} \mathrm{C}\right)$, intermediate for Hijuela Los Chilcos-Galvarino-Cautín (25.7 ${ }^{\circ} \mathrm{C}$ ) and Escuadrón-Coronel-Concepción (23.9 ${ }^{\circ} \mathrm{C}$ ) and lower for LicancullinV-Toltén-Cautín $\left(21^{\circ} \mathrm{C}\right)$. The rainfall is highest for LicancullinVToltén-Cautín (1994 mm), followed by Hijuela Los Chilcos-Galvarino-Cautín (1354 mm), Escuadrón-Coronel-Concepción (1134 mm), Yumbel-Bío-Bío (1093 mm) and MontoneraPencahue-Talca (709 mm).
The soils in Montonera-Pencahue-Talca correspond to the Ninhue series (Fluvaquentic Eutrochrepts; Inceptisol), which are deep alluvial soils with imperfect drainage formed from granitic material (CIREN, 1997). The soils in Escuadrón-Coronel-Concepción correspond to the Nahuelbuta association (Rhodic Paleudults; Ultisol), which are deep soils formed from metamorphic rocks, especially phyllites and micaschist, with a clay texture with a brown reddish color in the upper horizons and silty clay loam and silty clay textures in the deeper horizons. The Misque-Yumbel-Bío-Bío soils correspond to the Arenales series (Dystric Xeropsamments; Entisol), which are recent deep alluvial soils with scarce development. These soils are derived from black volcanic andesitic and basaltic sands and are coarse-textured throughout the entire profile. The Huinanco-Yumbel-Bio-Bío soils correspond to the Cauquenes Association (Ultic Palexeralfs; Alfisol), which are deep soils formed in situ from granitic rocks with clay textures throughout the entire profile (CIREN, 1999). The soils from Hijuela Los Chilcos-Galvarino-Cautín correspond to the Lumaco Series (Fluventic Dystrudepts; Inceptisol), which are formed from metamorphic rocks and

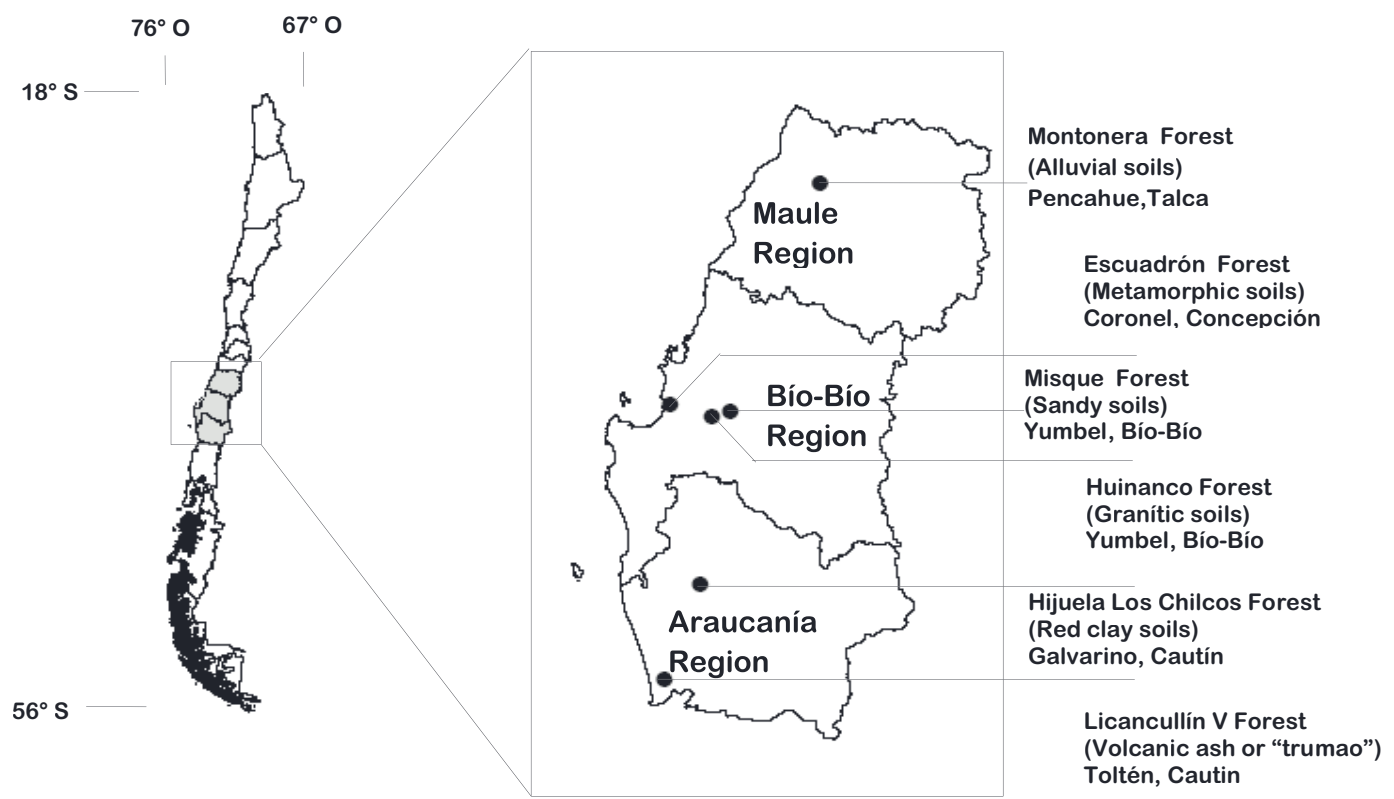

Figure 1. Locations where the pairs of two-year-old Pinus radiata trees with and without leaning were sampled for the study. 
have a silty clay loam texture, a brown reddish color and gravel and quartz gravel throughout the entire profile. The LicancullinV-Toltén-Cautín soils correspond to the Correltúe Series (Andic Haplohumults; Ultisol), which are deep soils developed from old volcanic ashes deposited on a metamorphic complex that is located mainly in the coastal range in central Chile (CIREN, 2002).

\section{Selection and extraction of trees}

A total of 72 trees were destructively sampled: 36 straight trees and 36 inclined trees. The leaning angle of the inclined trees varied between $21^{\circ}$ and $50^{\circ}$ sexagesimals, while the leaning direction, measured as the azimuth, was between $15^{\circ}$ and $273^{\circ}$ sexagesimals (Figure 2). Six pairs were selected per soil type, three from areas with ripping and three from areas without ripping. The trees sampled within each site were similar in size and were selected under equivalent slope and aspect conditions. Although the number of replicates was small, the plant material was derived from selected seeds, presenting high phenotypical homogeneity. However, the restrictions presented by studies on roots, which are costly in resources and time consuming, did not allow the extraction of a larger sample.

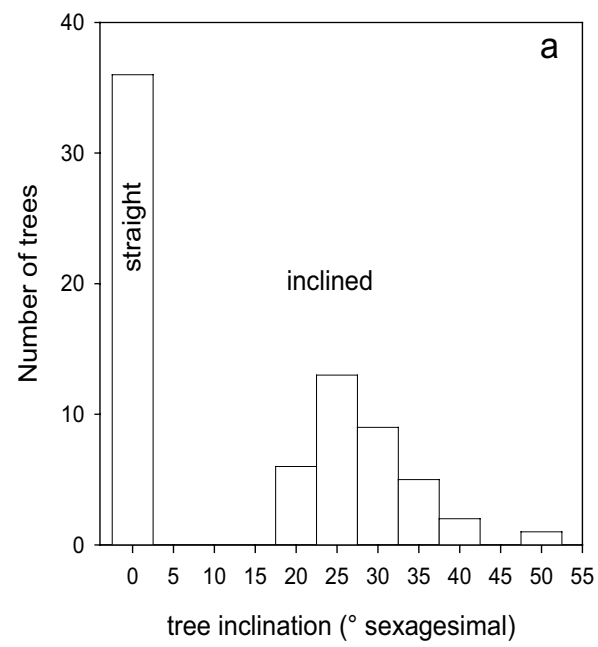

The selection criteria for the pairs of trees sampled were the following: (i) one tree of the pair presented some degree of leaning due to wind, while the other tree was completely straight; (ii) the type of soil and the establishment regime were equal for both trees; (iii) the two trees were similar in height and stem diameter at $10 \mathrm{~cm}$ from the ground; and (iv) the separation between trees was less than 10 meters. The aforementioned criteria allowed us to select pairs of trees that were similar in each aspect, except for the leaning caused by wind, which is equivalent to the methodology used by Mason (1985).

\section{Measurements and classification of roots}

The height, diameter at breast height and stem diameter at $10 \mathrm{~cm}$ from the base for each tree selected were measured. Subsequently, the roots were dug carefully and manually in a $60 \mathrm{~cm}$ radius from the tree axis, removing the soil adhered to the roots (Lario et al., 2005). The root system was divided into three components: tap root, lateral roots (arbitrarily defined as those roots with an angle lower than $45^{\circ}$ with respect to the horizontal soil plane) and vertical roots (defined as the roots with an angle higher than $45^{\circ}$ with respect to the horizontal soil plane).

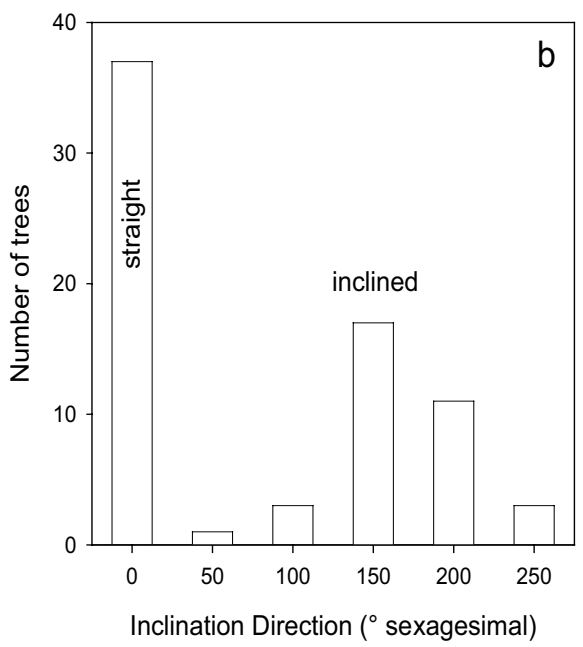

Figure 2. Frequency distribution of the leaning angles and directions (azimuths) of selected P. radiata trees (pairs: one with and one without leaning) in the central south of Chile. 
The tree stem was considered the center of a circumference divided into four quadrants of equal size, with quadrant one corresponding to the direction the tree was leaning and the remaining three quadrants numbered progressively clockwise. The diameters and vertical angles of all lateral and vertical roots larger than $2 \mathrm{~mm}$ at $10 \mathrm{~cm}$ from the base were recorded in each quadrant. Then, the Shannon-Wiener diversity index was calculated (Magurran, 2004), which may be expressed as:

$H^{\prime}=\sum_{i=1}^{4}-p_{\mathrm{i}} \ln p_{\mathrm{i}}$

where $p_{\mathrm{i}}$ represents the relative abundance of roots larger than $2 \mathrm{~mm}$ in quadrant $\mathrm{i}$, calculated as $n_{\mathrm{i}} / N$, where $n_{\mathrm{i}}$ is the number of roots in quadrant $\mathrm{i}$ and $N$ is the total number of roots in all the quadrants. Complementarily, the Shannon homogeneity index (E) was used, calculated as $H^{\prime} / \operatorname{Ln} S$, where $S$ is the number of quadrants. The Menzies classification tables were used for classification of the form of the tap and lateral roots (Mason, 1985), through which the quality of a root is assessed on a scale from 0 (best) to 10 (worst) (Figure 3).

\section{Value Form Diagram}

\section{Description}

Tap root strong, dominant and well developed

Tap root well defined, slightly deformed and shortened

Tap root bent

Tap root very bent, but still growing downward

Tap root severely deformed, with two or more fracture zones, but still growing downward

Tap root growing horizontally or no tap root

Figure 3. Menzies tap root quality classes (Mason, 1985). The index ranges from 0 for a high quality root to 10 for a low quality root.

\section{Statistical analysis}

The data was analyzed as a fixed effects linear model, with a three-factor arrangement: condition of the tree (toppled or straight), type of soil (alluvial, sandy, granitic, metamorphic, red clay and soils derived from volcanic ashes called "trumaos") and soil preparation (with ripping or without ripping). The main and interactive effects of the soil type, ripping and leaning on tree size and root variables were examined by analysis of variance. The least significant difference Tukey test was used to test whether pairs of treatment averages were different with a confidence level of $\mathrm{P} \leq 0.05$. Probit and logit regressions were used to test the influence of tree size and root variables on tree leaning by wind. The statistical analysis was made using the "glm" procedure of the R language (Ihaka and Gentleman, 1996). The values of the Wald $z$ statistic, the associated values of probability (P) and the Akaike Information Criterion (AIC) were used to evaluate the fitness of the probit and logit models with different sets of tree size and root variables. The AIC is an index of the goodness-of-fit of a statistical model; the lower the value, the better the model.

\section{Results}

The range of tree height for the trees sampled (72) varied between 180 and $390 \mathrm{~cm}$, with diameters in the stem base between 3.5 and $11.8 \mathrm{~cm}$ and slenderness coefficients (i.e., height divided by diameter) between 25 and 57.

The toppled and straight trees were very similar in regard to basal diameter and height $\left(\mathrm{F}_{1,48}<0.14\right.$; $\mathrm{P}>0.71)$. However, as expected, the tree basal diameter, height and slenderness were significantly influenced by the main effects of soil type $\left(\mathrm{F}_{5,48}>\right.$ 9.3; $\mathrm{P} \leq 0.001)$, ripping $\left(\mathrm{F}_{1,48}>17.1 ; \mathrm{P} \leq 0.001\right)$ and, to a lesser extent, by their interactive effect $\left(F_{5,48}\right.$ $>2.6 ; \mathrm{P} \leq 0.04$ ) (Figure 4, only height). 


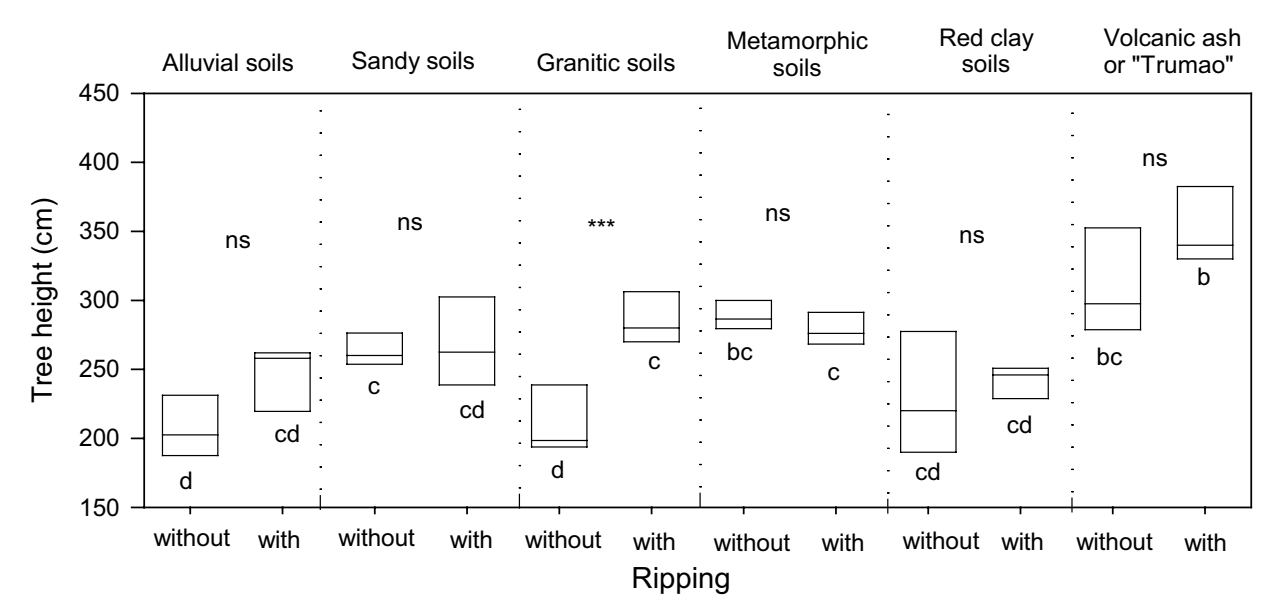

Figure 4 Influence of soil type and site preparation on tree heights. The values presented are the 25, 50 and 75 percentiles. The main and interactive effects of soil and ripping were significant at $\mathrm{P} \leq 0.01$. The differences between trees growing on sites with and without ripping are indicated as ns: non-significant and $* * *$ : significant at $\mathrm{P} \leq 0.001$. Different letters indicate significant differences at $\mathrm{P} \leq 0.05$.

Among all of the traits of the root system analyzed, only the tap root quality measured through the Menzies scale significantly affected the probability of leaning by wind $(z=2.36, \mathrm{P}=0.02)$ (Table 1$)$. Although the other variables were not significant, the depth of the first lateral roots $(\mathrm{P}=0.25)$, the average diameter of the vertical roots $(\mathrm{P}=0.31)$ and the total amount of vertical roots of the tree $(\mathrm{P}=0.44)$ were closer to explaining the leaning. The distribution of the lateral roots, the Shannon's diversity and homogeneity indices and the quality of the lateral roots measured through the Menzies scale did not show significant relationships with toppling probabilities $(\mathrm{P}>0.50)$. This result was also proved by comparing the lateral root variables (amount, diameter, Menzies scale and Shannon diversity and homogeneity indices) of toppled and untoppled trees using analysis of variance. Only the main effects of ripping and soil type had a significant effect $(\mathrm{P} \leq 0.036)$ on these variables.

The probability of tree toppling increased significantly from 0.34 for a Menzies tap root value of 0 to 0.72 for a Menzies value of 10 (Figure 5). A $50 \%$ probability of toppling was found for Menzies tap root values of 4.07 (probit) and 4.02 (logit). Under a Menzies value of approximately 4 , the trees are less likely to topple, but over this value, they are more likely to topple.

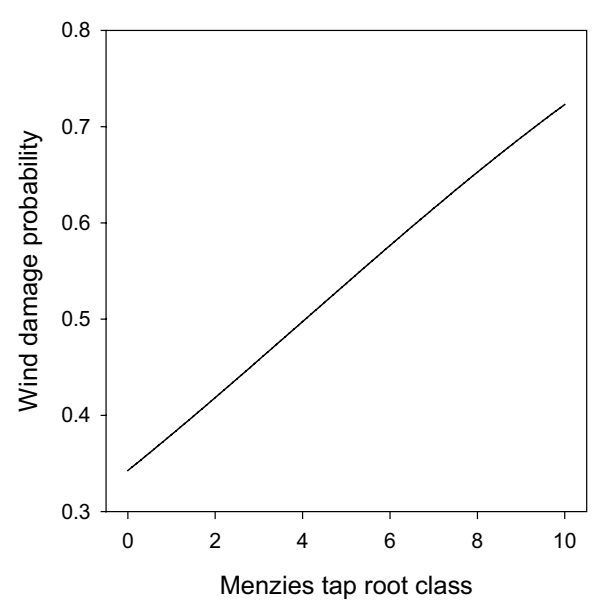

Figure 5. Probit regression model of the relationship between wind damage probability and the Menzies tap root quality index. The fit of the selected probit model was as follows: $\mathrm{z}=-0.40544+0.9972 \mathrm{M}, \mathrm{p}=\Phi(\mathrm{z})$, standard normal distribution. The logit model shows equivalent results to the probit model: $\mathrm{p}=\mathrm{e}^{-0.65110+0.16213 \mathrm{M}} /\left(1+\mathrm{e}^{-0,65110}\right.$ $+0.16213 \mathrm{M})$, where $\mathrm{p}$ is the probability of damage and $\mathrm{M}$ is the tap root quality index.

The Menzies tap root quality class was significantly influenced by the main effects of soil type $\left(\mathrm{F}_{5,48}=3.16 ; \mathrm{P}=0.02\right)$, ripping $\left(\mathrm{F}_{1,48}=20.7\right.$; $\mathrm{P} \leq 0.001)$ and tree leaning $\left(\mathrm{F}_{1,48}=8.7 ; \mathrm{P}=0.005\right)$ but not by their interactive effects $\left(\mathrm{F}_{1-5,48}<2.3\right.$; $\mathrm{P}>0.053$ ) (Figure 6). Considering the $F$-values for the main effects, ripping was 6.6 times more important than soil type. 
Table 1. Measured root and aerial variables of Pinus radiata trees with and without leaning growing in ripped and unripped soils in central south Chile. Probit relationship significance was measured through the $\mathrm{z}$ value, the $\mathrm{P}$ value and the Akaike information criterion (AIC), a goodness-of-fit criterion (less is better). The significance using the probit regression model was equivalent to that found using the logit regression model.

\begin{tabular}{|c|c|c|c|c|c|c|c|c|c|c|c|}
\hline \multirow[b]{3}{*}{ Variables } & \multicolumn{4}{|c|}{ Without Ripping } & \multicolumn{4}{|c|}{ With Ripping } & & & \\
\hline & \multicolumn{2}{|c|}{ Without Leaning } & \multicolumn{2}{|c|}{ With Leaning } & \multicolumn{2}{|c|}{ Without Leaning } & \multicolumn{2}{|c|}{ With Leaning } & \multicolumn{3}{|c|}{ Probit Regression } \\
\hline & mean & range & mean & range & mean & range & mean & range & $\mathrm{z}$ & $\mathrm{P}$ & $\mathrm{AIC}$ \\
\hline Height $(\mathrm{cm})$ & 251 & $180-350$ & 253 & $190-360$ & 279 & $218-380$ & 278 & $220-390$ & 0.080 & 0.936 & 103.81 \\
\hline Stump diameter $(\mathrm{cm})$ & 6.5 & $3.5-11.2$ & 6.3 & $3.5-9.8$ & 7.7 & $4.9-10.2$ & 8.0 & $5.1-11.8$ & 0.205 & 0.837 & 103.77 \\
\hline Slenderness ratio & 41 & $25-54$ & 42 & $31-57$ & 37 & $28-52$ & 35 & $25-45$ & -0.236 & 0.814 & 103.76 \\
\hline Tap root diameter $(\mathrm{mm})$ & 21.8 & $0-80$ & 14.3 & $0-45$ & 22.6 & $0-46$ & 25,8 & $0-40$ & -0.644 & 0.520 & 103.40 \\
\hline First root depth $(\mathrm{cm})$ & 6.4 & $3-10$ & 7.3 & $2-15$ & 9.4 & $3-20$ & 10.8 & $4-25$ & 1.142 & 0.253 & 102.50 \\
\hline Tap Root Class (Menzies) & 4.8 & $0-10$ & 6.6 & $2-10$ & 1.3 & $0-10$ & 3.7 & $0-10$ & 2.357 & 0.0184 & 98.00 \\
\hline $\begin{array}{l}\text { Lateral Root Class } \\
\text { (Menzies) }\end{array}$ & 4.1 & $0-10$ & 4.3 & $0-8$ & 2.8 & $0-8$ & 2.4 & $0-6$ & -0.093 & 0.926 & 103.80 \\
\hline $\begin{array}{l}\text { Average diameter of } \\
\text { vertical roots }(\mathrm{mm})\end{array}$ & 13.2 & $0-48$ & 8.3 & $0-21$ & 13.5 & $0-21$ & 14.3 & $0-30$ & -1.014 & 0.311 & 102.79 \\
\hline $\begin{array}{l}\text { Average diameter of lateral } \\
\text { roots }(\mathrm{mm})\end{array}$ & 4.5 & $1.4-9.3$ & 4.2 & $1.5-11.2$ & 5.8 & $1.5-10.7$ & $6-1$ & $1.9-13.4$ & -0.012 & 0.990 & 103.81 \\
\hline Vertical root area $\left(\mathrm{mm}^{2}\right)$ & 279 & $0-1.200$ & 305 & $0-1.200$ & 470 & $0-2.520$ & 409 & $0-1.000$ & -0.196 & 0.844 & 103.78 \\
\hline Lateral root area $\left(\mathrm{mm}^{2}\right)$ & 998 & $60-4.145$ & 951 & $123-3.506$ & 1666 & $258-5.315$ & 1669 & $173-3.957$ & -0.086 & 0.931 & 103.81 \\
\hline Vertical root quantity & 4.9 & $0-10$ & 6.9 & $0-15$ & 8.2 & $0-25$ & 8.1 & $0-17$ & 0.771 & 0.441 & 103.20 \\
\hline Lateral root quantity & 19.8 & $4-46$ & 18.5 & $7-35$ & 22.7 & $5-46$ & 22.1 & $9-40$ & -0.434 & 0.664 & 103.62 \\
\hline $\begin{array}{l}\text { Shannon Diversity Index } \\
\left(\mathrm{H}^{\prime}\right)\end{array}$ & 0.92 & $0.02-1.36$ & 0.77 & $0.02-1.36$ & 0.96 & $0.02-1.39$ & 1.01 & $0.65-1.39$ & -0.682 & 0.495 & 103.34 \\
\hline $\begin{array}{l}\text { Shannon Homogeneity } \\
\text { Index (E) }\end{array}$ & 0.67 & $0.01-0.98$ & 0.56 & $0.01-0.98$ & 0.69 & $0.01-1.00$ & 0.73 & $0.47-1.00$ & -0.682 & 0.495 & 103.34 \\
\hline
\end{tabular}

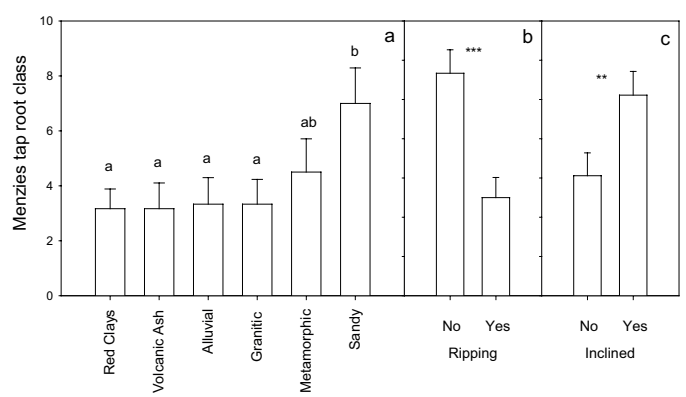

Figure 6. Main effects of (a) soil type, (b) ripping and (c) tree inclination on the Menzies tap root quality index. Values are presented as the means ( \pm 1 standard error). Different letters indicate significant differences at $\mathrm{P} \leq 0.05$ in (a). Significance in (b) and (c) are presented as **: $\mathrm{P} \leq 0.01 ; * * *: \mathrm{P} \leq 0.001$.

The trees growing in ripped soils had a Menzies tap root value ( \pm standard error) of $2.5 \pm 0.5$, which is less than half the values found in the unripped soils $(5.7 \pm 0.6)$. According to the probit model fit, this result would translate to toppling probabilities of 0.44 for ripped soils compared with 0.56 for unripped soils (Figure $6 \mathrm{~b}$ ).

Toppled trees had a Menzies tap root quality $( \pm$ standard error) of $5.1 \pm 0.6$, which is 1.6 times higher (worse quality) than the averages found in trees without leaning $(3.1 \pm 0.6)$. Applying the fitted probit model (Figure 4), the leaning trees would exhibit a toppling probability of 0.54 compared with 0.46 for straight trees (Figure 6c).

Although less important, soil type was also related to the Menzies tap root quality class and, therefore, to the toppling probability. The highest Menzies values (worse tap root quality) were found in trees growing in sandy soils $(7.0 \pm 1.3)$, followed by metamorphic soils $(4.5 \pm 1.2)$. The alluvial soils, granitic soils, red clay soils and trumaos did not differ, with an average value of $3.3 \pm 0.9$ (Figure 
6a). This result showed probabilities of toppling damage of 0.62 for sandy soils, 0.52 for metamorphic soils and 0.47 for the other types of soil studied (based on probit regression).

Tree size and slenderness have an effect on neither the Menzies tap root quality class $\left(\mathrm{r}^{2}<0.03\right.$; $\mathrm{P}>$ 0.14 ) nor, consequently, on the toppling probability. This result shows that the effects of ripping and soil type on leaning trees are independent of their size.

\section{Discussion}

This study showed that the probability of toppling damage increases as the tap root quality decreases. It was observed that trees with a strong, dominant and well-developed tap root (Menzies values equal to zero) present a probability of damage occurrence of 0.34 (one out of three trees might be damaged). However, trees with a tap root that grows horizontally or without a tap root (Menzies values equal to 10) presented a probability of damage of 0.72 , which is equivalent to 3 out of 4 trees damaged. A probability value of 0.50 (one out of two trees damaged) was found for trees with a bent but functional tap root (Menzies value equal to four). Mason (1985) also found that the quality of the tap root was the most important determining factor in toppling damage to $P$. radiata in New Zealand. This study confirms the results obtained by Mason (1985) and expands our understanding of toppling damage when proposing probability functions associated with the phenomenon.

In this study, we did not find significant differences among the amount, size and spatial homogeneity (measured by the Shannon indices) of lateral roots from stable or toppled-trees. Consequently, the presence of lateral roots did not decrease the probability of toppling damage. This result is also in accordance with the results obtained by Mason
(1985) in $P$. radiata plantations in New Zealand and $P$. pinaster in Spain (Lario et al., 2005).

In this study, as in Lario et al. (2008), ripping prior planting significantly improved the quality of the tap root, which in turn reduced the probability of toppling. This conclusion was valid for all soil types studied. Ripping is a procedure of soil preparation characterized by an important increase of effective soil depth, which favors the development of deeper roots (Mason, 2004). Mason (1985) indicated that ripping might increase the probability of damage because the trees would grow faster, except for compacted soils, where it might favor the development of the tap root, reducing the probability of damage. In this study, however, ripping before planting increased the firmness and development of the tap root in all soils, reducing the probability of toppling damage.

It has been suggested that the probability of damage by wind increases in more fertile soils due to the highest growth rates in terms of the height of the trees and the higher proportion of aerial mass in relation to the root biomass (Watson and Tombleson, 2002; Moore et al., 2008). The results found do not agree with this hypothesis for the soils under study. The effects of soil type and ripping on the probability of toppling seem to operate through the development and quality of the tap root. Sandy soils, which are far from the most fertile, exhibited the worst tap root quality and, therefore, higher probabilities of damage by wind. In contrast, trees growing in more fertile soils (trumaos) showed good tap root quality and development; therefore, the toppling probability was low.

In conclusion, the stability of young trees of $P$. radiata is related to the development of strong and well-formed tap roots. Ripping significantly improved the quality and development of the tap root, reducing the probability of damage by wind. Additionally, trees in more fertile soils 
(trumaos) presented a better quality of tap roots than less fertile soils (sandy soils) and, therefore, a lower probability of damage. Consequently, all the measures favoring the developing of a strong and well-formed tap root in the nursery and in the field would likely reduce the probability that the trees would be inclined (toppled) by wind.

\section{Acknowledgments}

We wish to thank Forestal Mininco S.A. for their support and help given to Mr. Alejandro Mañón in his research, which was part of his Master's Thesis in Forest Sciences from Universidad de Chile.

\title{
Resumen
}

\begin{abstract}
M. Toral, H.E. Bown, A. Mañon, J. Alvarez y R. Navarro-Cerrillo. 2011. Inclinación por viento en plantaciones juveniles de Pinus radiata, en Chile. Cien. Inv. Agr. 38(3): 405-414. La inclinación de árboles jóvenes de Pinus radiata por efecto del viento reduce el valor comercial de la primera troza en esta especie. A pesar de que el viento es la causa fundamental del daño, se ha observado que la calidad y tipo de plantas utilizadas, la técnica de plantación, la fertilidad y la preparación del suelo, tienen un efecto agravante en la susceptibilidad de daño en esta especie. Este artículo analiza el efecto del subsolado y del tipo de suelo en la probabilidad de inclinación de $P$. radiata posterior a tormentas de viento en el centro-sur de Chile. Para ello, se seleccionaron parejas de árboles similares con y sin inclinación, en seis tipos de suelos con y sin subsolado, y se analizó cómo las diferencias en los sistemas radicales de los árboles contribuyen a una mejor comprensión de las causas de esta inclinación. Entre todas las variables medidas en los sistemas radicales, la escala de calidad de la raíz pivotante de Menzies resultó altamente significativa en explicar la probabilidad de daño causada por el viento. Se encontró que árboles con una raíz pivotante fuerte, dominante y bien desarrollada (Menzies $=0$ ), presentan una probabilidad de ocurrencia de daño de 0.34 . Por otro lado, árboles con una raíz pivotante creciendo horizontalmente, o sin raíz pivotante (Menzies $=10$ ), presentaron una probabilidad de daño de 0.72 . El valor de probabilidad 0.50, o que uno de cada dos árboles sea dañado-, se encontró para árboles con raíces pivotantes dobladas pero funcionales (Menzies=4). El subsolado mejoró sustancialmente la calidad y desarrollo de la raíz pivotante (desde Menzies 5.7 a Menzies 2.5) reduciendo la probabilidad de daño por viento desde 0.56 a 0.44 . Las peores calidades de raíces pivotantes fueron encontradas en los suelos de Arenales (Menzies de 7.0 con probabilidad de daño de 0.62), seguido por los suelos metamórficos (Menzies de 4.5 con probabilidad de daño de 0.52 ). La calidad de la raíz pivotante no difirió entre suelos aluviales, graníticos, rojos arcillosos y trumaos (Menzies de 3.3 con probabilidad de daño de 0.47 ). En consecuencia, todas aquellas medidas que favorezcan el desarrollo de la raíz pivotante en el vivero y en el terreno, reducirán las probabilidades que los árboles sean inclinados por efecto del viento en plantaciones jóvenes de $P$. radiata en Chile.
\end{abstract}

Palabras clave: Fertilidad de suelos, inclinación por viento, raíz pivotante, subsolado.

\section{References}

Aimers-Halliday, J., G. Holden, B. Klomp, and M. Menzies. 1999. Soften the blow - plant aged cuttings on topple-prone sites. What's news in forest research? New Zealand Forest Research Institute. Rotorua, New Zealand. No. 248: 1-4.
Bown, H.E.; M.S. Watt, P.W. Clinton, and E.G. Mason. 2011. Soil $\mathrm{C} / \mathrm{N}$ influences the carbon flux and partitioning in control and fertilized miniplots of Pinus radiata in New Zealand Cien. Inv. Agr. 38:277-289.

Beets, P.N. and D. Whitehead. 1996. Carbon partitioning in Pinus radiata stands in relation to foliage nitrogen status. Tree Physiol. 16:131-138. 
Burdett, A.N., H. Coates, R. Eremko, and P.A.F Martin. 1986. Toppling in British Columbia's lodgepole plantations: significance, cause and prevention. Forest Chronicle 62:433-439.

Cendoya, P., and F. Muñoz. 2002. Modelamiento del efecto del viento sobre árboles jóvenes de Pinus radiata D. Don. Bosque 23(2): 51-56.

CIREN. 1997. Estudio Agrológico: VII Región. Centro de Información de Recursos Naturales. Chile. Publicación CIREN No 117. 611 pp.

CIREN. 1999. Estudio Agrológico: VIII Región. Centro de Información de Recursos Naturales. Chile. Publicación CIREN No 121. 555 pp.

CIREN. 2002. Estudio Agrológico: IX Región. Centro de Información de Recursos Naturales. Chile Publicación CIREN No 122.343 pp.

Chavasse, C.G.R. 1969. Instability in young stands. Farm Forestry 11(3):70-77.

Cown, D., D. McConchie, and C. Trebolar. 1984. Timber recovery from pruned Pinus radiata buttlogs at Mangatu: Effect of log sweep. New Zealand Journal of Forestry Science 14: 109-123.

Coxe, I., J. Aimers-Halliday, M. Menzies, and G. Holden. 2004. Toppled pines - can they be fixed? Results from three toppling trials at Waiotira, Northland. New Zealand Journal of Forestry 49: 17-23.

Davies-Colley, P., and J. Turner. 2001. The effects of a crown lightening technique on growth and form, and topple in two-year-old Pinus radiata. New Zealand Journal of Forestry 46: 23-29.

Ihaka, R., and R.Gentleman. 1996. R: A language for data analysis and graphics. Journal of Computational and Graphical Statistics 5: 299-314.

Lario, F.J., Fernández, E., López, B., Ocaña, L., Rodríguez, R. 2008 "Inclinación del tallo de planta de Pinus pinaster Ait. en función del contenedor y duración del cultivo" Cuad. Soc. Esp. Cienc. For. 28: 195-200.

Lario, F.J., L. Ocaña, J.R. Rodríguez, and J.A. Gómez. 2005. Calidad de forma del fuste de Pinus pinaster Aiton en clima atlántico. Modelo radical para la predicción en plantaciones juveniles. IV Congreso Forestal Español, Zaragoza, Sociedad
Española de Ciencias Forestales. Zaragoza, España. s/p.

Mason, E. 1985. Causes of juvenile instability of Pinus radiata in New Zealand. New Zealand Journal of Forestry Science 15: 263-280.

Mason, E., and A. Trewin. 1987. Toppling of radiata pine. What's news in forest research? New Zealand Forest Research Institute. Rotorua, New Zealand. No. 147:1-4.

Mason, E. 1992. Decision support systems for establishing radiata pine plantations in the Central North Island of New Zealand. Ph.D. Dissertation, University of Canterbury. 250 pp.

Mason, E. 2004. Effects of soil cultivation, fertilisation, initial seedling diameter and plant handling on the development of maturing Pinus radiata D. Don on Kaingaroa gravely sand in the Central North Island of New Zealand. Bosque 25(2): 43-55.

Magurran, A.E. 2004. Measuring biological diversity. Blackwell Publishing, Oxford, UK. 248 pp.

Moore, J.R., J.D.Tombleson, J.A. Turner, and M. Van Der Colff. 2008. Wind effects on juvenile trees: a review with special reference to toppling of radiata pine growing in New Zealand. Forestry 81: 377-387.

Santantonio, D., and E. Santantonio. 1987. Seasonal changes in live and dead fine roots during two successive years in a thinned plantation of Pinus radiata in New Zealand. N.Z. J. For. Sci. 17:315-328.

Santibáñez, F., and J.M. Uribe. 1993. Atlas agroclimático de Chile: Regiones Sexta Séptima Octava y Novena. Universidad de Chile, Facultad de Ciencias Agrarias y Forestales, Lab. de Agroclimatología. Santiago, Chile. 99 pp.

Trewin, R. 2003. What can we do about toppling? Establishment problems and remedies. New Zealand Journal of Forestry: 32-36.

Watson, A.J., and J.D. Tombleson, 2002. Toppling in juvenile pines: A comparison of the root system characteristics of direct-sown seedlings, and bare-root seedlings and cuttings. Plant and Soil 239:187-196. 